\title{
Commentary: Old enough to know better
}

\author{
John Swanson, MD, ${ }^{a}$ and Alden Harken, $\mathrm{MD}^{\mathrm{b}}$
}

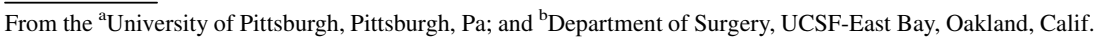
Disclosures: Authors have nothing to disclose with regard to commercial support.

Received for publication July 17, 2019; accepted for publication July 17, 2019; available ahead of print Aug 27, 2019.

Address for reprints: Alden Harken, MD, Department of Surgery, UCSF-East Bay, 1411 E 31 St, Oakland, CA 94516 (E-mail: Alden.harken68@gmail.com).

J Thorac Cardiovasc Surg 2020;159:2272

0022-5223/\$36.00

Copyright (c) 2019 Published by Elsevier Inc. on behalf of The American Association for Thoracic Surgery

https://doi.org/10.1016/j.jtcvs.2019.07.041

As children and cardiomyocytes grow they achieve recognizable milestones. With kids there are specific ages when they are supposed to be able to sit up, walk, read, and drive a car. Aoyama and colleagues ${ }^{1}$ argue that similar maturational milestones are accomplished for cardiac cells when the baby cells gain ion channels, gap junctions, and electrophysiological stability. With the advent of stem cell regenerative therapy it is critically important that we know how capably mature a donor cell must be before it can be stuffed into a postinfarction scar with the realistic expectation of contractile participation. So again, for kids and cells, the kindergarten teachers and the cell biologists are focused on the same end point - at what age have the little devils learned to play together. And again, the teachers and the scientists view identical spatiotemporal indicators of success. In school it's the age that the kids stop hitting each other in the sandbox and in the Petri dish it's the age at which the cells initiate synchronous contractions. The strength of the accompanying report is its goal. It would be really nice to know the optimal age of the donor cells we should inject into uncle Frank's heart attack. We are learning from multiple studies however, that the environment the donor cells encounter is pivotal to their successful survival and function. Or, reverting back to people, are the skills for survival and function for kids growing up in Hollywood identical to the attributes essential for kids in Dead Gulch, Nebraska, or Silicon Valley?

It is time for cardiovascular surgeons to familiarize ourselves with cellular regenerative vernacular. So let's step back and define the author's experimental animal-the stem cell. There are two broad types of stem cells-the adult and the embryonic. And again like people the older you are the harder it is to learn. Adult (or progenitor) stem cells are lineage restricted and are identified by their

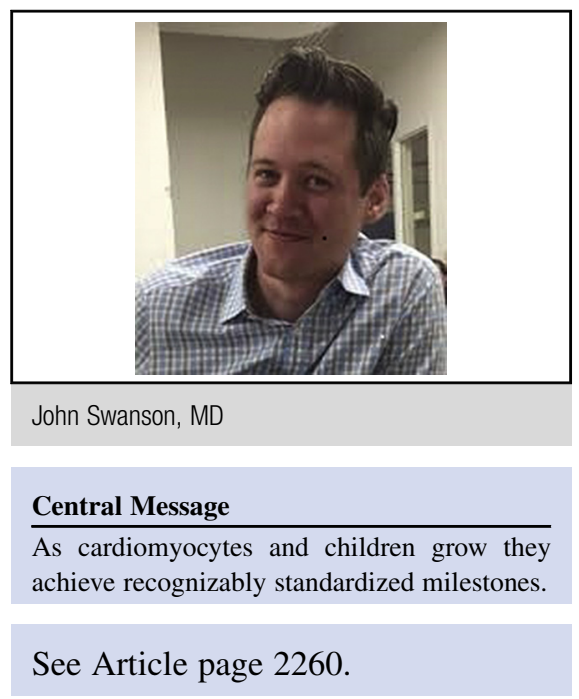

source (mesenchymal or adipose derived or cardiac) stem cells. These stem cells repair and maintain the organs in which they reside. Although the term stem cell and progenitor cell are commonly used interchangeably, a progenitor cell has limited replication capacity whereas a stem cell can go on dividing forever.

Embryonic stem cells are at the blastocyst stage or 4 to 5 days postfertilization of the ovum. At this very early phase they can mature into any kind of specialized cell. As these maximum potential stem cells can only be harvested from embryos, human embryonic stem cells are also maximally (biologically, politically, and ethically) inaccessible. Fortunately methods to induce human pluripotent stem cells, directly from adult cells are now available.

The authors have used spatiotemporal imaging analysis, quantitative polymerase chain reaction, and immunohistochemistry to suggest that a differentiation period of more than 70 days correlates with a cardiomyocyte's ability to fly in formation with its siblings. Is this like linking ability to drive with ready for college?

\section{Reference}

1. Aoyama J, Homma K, Tanabe N, Sumiko Usui, Miyagi Y, Matsuura K, et al Spatiotemporal imaging documented the maturation of the cardiomyocytes from human induced pluripotent stem cells. J Thorac Cardiovasc Surg. 2020;159: 2260-71.e7. 